\title{
Physical activity patterns in adults: prevalence and associated factors
}

\author{
Padrão de atividade física em adultos: \\ prevalência e fatores associados
}

\author{
Nathalia Cristine Fraga ${ }^{1}$, Nicoly Machado Maciel ${ }^{1}$, Caio Vitor dos Santos Genebra ${ }^{1}$, \\ José Paulo Candido ${ }^{1}$, Thiago Paulo Frascareli Bento ${ }^{1}$, Guilherme Porfírio Cornelio', \\ Rangel dal Bello Biancon ${ }^{1}$, Alberto De Vitta ${ }^{2}$
}

\begin{abstract}
Background: Insufficient practice of physical activity associated with some factors related to life habits increase the risk of non-transmissible chronic diseases and reduce quality of life. Objective: Identify the pattern of physical activity and associated factors in adults aged $\geq 20$ years. Method: A cross-sectional, population survey conducted with 600 individuals. Data on demographic, socioeconomic and behavioral aspects, work, and physical activities were collected through home interviews. Descriptive, bivariate and Poisson regression analyses were performed. Results: Prevalence of insufficient physical activity was 35.0\% (95\% Cl: 31.2-38.9). Zero to four years of schooling [PR=2.35; $95 \% \mathrm{Cl}: 1.07-5.15]$, working in sitting position [PR=1.52; 95\% Cl: 1.02-2.48], and number of days at the computer [PR=4.60;95\% Cl: 2.38-14.28] remained in the final model for females, whereas $0-4$ years [PR=2.30; 95\% Cl: 1.21-4.06] or 5-8 years [PR=3.70; 95\% Cl: 0.79-4.00] of schooling, working in sitting position [PR=2.22 95\% Cl: 1.36-3.62], number of days at the computer [PR=2.04; 95\% Cl: 1.26-3.32], and number of days of TV viewing [PR=2.12; 95\% $\mathrm{Cl}: 1.03-4.36$ ] remained in the final model for males. Conclusion: High prevalence of insufficient practice of physical activity is associated with schooling, working in sitting position, and number of days at the computer and TV viewing.
\end{abstract}

Keywords: sedentary lifestyle; cross-sectional studies; physical activity; associated factors.

\begin{abstract}
Resumo
Introdução: A prática insuficiente de atividade física associada a alguns fatores relacionados aos hábitos de vida aumenta o risco de doenças crônicas não transmissíveis e reduz a qualidade de vida da população. Objetivo: Identificar o padrão de atividade física e os fatores associados em adultos de 20 anos ou mais. Método: Inquérito populacional, transversal, com 600 indivíduos entrevistados em seus domicílios. Foram coletados os seguintes dados: aspectos demográficos, socioeconômicos, comportamentais, do trabalho e nível de atividade física. Realizaram-se as análises descritiva e bivariada e a regressão de Poisson. Resultados: A prevalência de prática insuficiente de atividade física foi de 35\% (IC 95\%: 31,2-38,9). O nível educacional de 0 a 4 anos [RP = 2,35; IC95\%: 1,07-5,15], o trabalho sentado [RP = 1,52; IC95\%: 1,02-2,48] e o número de dias no computador [RP = 4,60; IC95\%: 2,38-14,28] permaneceram no modelo final para o sexo feminino. Para o sexo masculino, permaneceram: o nível educacional de 0 a 4 anos [RP = 2,30; IC95\%: 1,21-4,06] ou o de 5 a 8 anos [RP = 3,70; IC95\%: 0,79-4,00], o trabalho sentado [RP = 2,22; IC95\%: 1,36-3,62], o número de dias no computador [RP = 2,04; IC95\%: 1,26-3,32] e o número de dias na TV [RP = 2,12; IC95\%: 1,03-4,36]. Conclusão: Houve elevada prevalência de prática insuficiente de atividade física e associação com nível de escolaridade, trabalho sentado e número de dias no computador e na TV.
\end{abstract}

Palavras-chave: estilo de vida sedentário; estudos transversais; atividade física; fatores associados.

${ }^{1}$ Universidade Sagrado Coração (USC) - Bauru (SP), Brasil.

${ }^{2}$ Universidade Estadual Paulista (UNESP) - Presidente Prudente (SP), Brasil.

Study carried out at Universidade do Sagrado Coração (USC) - Bauru (SP), Brasil.

Correspondence: Alberto De Vitta - Universidade Estadual Paulista (UNESP), Rua Roberto Simonsen, 305 - CEP: 19060-900 - Presidente Prudente (SP), Brasil Email: albvitta@gmail.com

Financial support: CNPq: 478188/2011-0 / FAPESP: 2011/20123-4.

Conflict of interests: nothing to declare.

This is an Open Access article distributed under the terms of the Creative Commons Attribution License, which permits unrestricted use, distribution, and reproduction in any medium, provided the original work is properly cited. 


\section{INTRODUCTION}

Insufficient practice of physical activity, along with smoking and inadequate diet, are considered essential elements for decreased quality of life of a population because they are the most common risk factors of chronic non-communicable diseases ${ }^{1,2}$.

Some studies have reported the indices of insufficiently active individuals among the Brazilian population. In Sao Paulo ${ }^{3}$, this index is $17.3 \%$; in Belo Horizonte ${ }^{4}, 33.7 \%$; in the south/northeast regions ${ }^{5}, 31.8 \%$; and for individuals interviewed by the National Health Survey (PNS), 46.0\% ${ }^{6}$.

Insufficient practice of physical activity is more evident in low schooling ${ }^{7,8}$ and income ${ }^{8,9}$, married ${ }^{7}$, obese ${ }^{9,10}$ females $^{7,10}$ with negative self-assessment of health ${ }^{9}$ who work more than eight hours a day and do sedentary activities during leisure and work times ${ }^{8}$.

Although the international and national literature addressing the epidemiology of physical activity has grown considerably in the past years, the present study is an advance in the knowledge regarding physical activity, because population-based studies and the use of variables associated with work and sedentary activities are scarce, according to search at the main databases. In addition, information on sedentary activities and work may guide intervention programs aimed at increasing physical activity, reducing sedentary behavior during adult life, and contributing to the daily recommendations of these behaviors.

In this context, this study aimed to identify the physical activity patterns and their associated factors in adults aged $\geq 20$ years.

\section{METHOD}

This is a cross-sectional, population study conducted in the urban area of the municipality of Bauru, Sao Paulo state, Brazil - a city with 316.064 inhabitants, where 207.021 of them are over 20 years old. The study was approved by the Research Ethics Committee of the Universidade do Sagrado Coração under protocol no. 957.481.

First, the age and gender groups were defined and named sample domains, and a minimum number of individuals were guaranteed to enable further analysis. The sample domains regarding age were as follows: 20-35-year males; 20-35-year females; 36 -59-year males; 36 -59-year females; $\geq 60$-year males; $\geq 60$-year females. Sample calculation was based on the estimated proportion in the population subgroups of $50 \%$ ( $p=0.50)$, because it is the maximum variability to obtain sizes of conservatory samples; a confidence interval of $95 \%(\mathrm{z}=1.96)$ was considered in the estimate; sample error indicating the amplitude between sample evaluation and population parameter should not exceed $10 \%(\mathrm{~d}=0.1)$; the design effect was equal to $2(\mathrm{deff}=2)$. Therefore, the sample size for the group was $\geq 200$ individuals ( 100 males and 100 females), with a total of 600 participants.
Sample draw was calculated by two-stage cluster. Census sectors constituted the primary sampling units (PSU), whereas the household sector comprised the secondary sampling unit. The PSU were randomly drawn with proportional probability of size. The samples were obtained by the National Household Sample Survey of 2010, which provides a list of private home addresses for each census sector. Fifty out of the 476 urban census sectors identified were drawn.

For each census sector, the number of households to be drawn was determined by calculating the mean ratio of individuals to the number of households in each sample domain ${ }^{6}$. Therefore, estimation showed that approximately 12 households should be visited by census sector. The households were drawn systematically, and all the individuals living in these households were considered eligible for interview. In the case of refusal, a new household was drawn.

Individuals who were not found after four visits - with at least one visit in the evening and one on the weekend, in addition to those who were traveling, were considered a loss. Refusals consisted of those who refused to respond to the questionnaire as a personal option.

Individuals who did not present mental conditions to respond to the questionnaire were excluded from the study. Elderly individuals were submitted to the Mini-Mental State Examination (MMSE) prior to the interview, and those who scored $\leq 27$ points were considered as presenting cognitive impairment and were, therefore, excluded ${ }^{11}$.

Interviews were conducted by trained examiners and the field work was overseen by the researchers. Data collection occurred from February to July 2012. Codification of the questionnaires was performed after the interviews by the interviewers themselves and reviewed by the researcher-in-charge. The supervisors also conducted quality control that consisted in applying the questionnaires with a reduced number of questions to $10 \%$ of the interviewees.

The study sample was characterized according to items associated with demographic aspects: gender (female or male), age, marital status (married or under consensual union, single, divorced, or widowed), and race (white, African descent, brown/mulatto, or Indian descent), as well as to socioeconomic aspects: schooling (number of years of education) and income (Class $\mathrm{E} \leq 1$ minimum wage; Class $\mathrm{D}=1-5$ minimum wages; Class $\mathrm{C}=5-10$ minimum wages; Class $\mathrm{B}=10-20$ minimum wages; Class $\mathrm{A}=>20$ minimum wages) ${ }^{12}$.

The following questions were asked regarding sedentary activities or use of electronic devices (time of TV viewing and at the computer and/or video game): "Do you watch TV?" (yes/no); "How often do you watch TV in a week?" (2/3-4/>5 days); "How long do you watch TV a day?" (>2/>3 hours); "How often do 
you use a computer or video game in a week?" (>2/3-4/>5 days); "How long use a computer or video game a day?" (>2/>3 hours) ${ }^{13}$.

Regarding tobacco use, individuals who reported smoking daily ( $\leq 1$ cigarette a day) or occasionally ( $<1$ cigarette a day) were considered smokers, whereas those who reported having stopped smoking at least six months before the time of interview were regarded as former smokers ${ }^{14}$.

The ergonomic variables were characterized by the interviewees' perception, who identified among four options (never, rarely, usually, or always) the one that best described the frequency of exposure performed when they were working or at the time of the interview. Physical effort, vibration, and repetitiveness, as well as poor posture characterized by the frequencies in which the interviewers worked sitting, standing, crouching, lying, or kneeling were among the variables measured. To define the association between low back pain and the ergonomic variables, the frequencies obtained in the "never" and "rarely" categories were added and categorized into one single group; the same was done for the categories "usually" and "always"15.

Physical activity practice (dependent variable) was evaluated using the short version of the International Physical Activity Questionnaire (IPAQ), recommended by the World Health Organization (WHO) for population-based studies ${ }^{16}$. From the continuous measures of physical activity scores based on Metabolic Equivalent of Task (MET) - MET-minutes/week, participants were initially classified into three levels: "insufficiently active", "active", and "very active". Participants who performed five or more days of any combination of walking, moderate or vigorous intensity activities, accumulating at least 600 MET-minutes/week, were classified as active; those who performed seven or more days of any combination of these activities, accumulating at least 3000 MET-minutes/week, were classified as very active; participants who did not meet either of the two previously mentioned criteria were considered insufficiently active. The "active" and "very active" categories were grouped into a single category, corresponding to sufficient physical activity practice, and those formerly classified as "insufficiently active" comprised the category corresponding to insufficient physical activity practice ${ }^{17,18}$.

\section{Statistical analysis}

Data were inserted into a database (SPSS 10.0, Chicago, USA), and the analyses were stratified by gender. Absolute and relative frequency distributions were performed for the categorical variables, and calculation of prevalence ratios (PR) was conducted at 95\% confidence interval (CI). Poisson regression was used to analyze the variables associated with low back pain respecting a hierarchical model of relations between the variables. The prevalence ratios and their respective $95 \%$ confidence intervals were calculated ${ }^{19}$.

\section{RESULTS}

Six hundred out of the 641 individuals eligible for interview identified in the randomly chosen households were adequately interviewed. The main reasons for this loss $(n=41)$ were "there was nobody at home" and "the individual arranged an appointment with the interviewer but did not attend it". The reasons for refusal were "I do not answer interviews" and "It is too long/I have no time to respond to an interview".

Table 1 shows the sociodemographic characteristics of the sample of individuals aged $\geq 20$ years residing in the municipality of Bauru. For both genders, there was predominance of white, married, low-income, non-smoking, eutrophic individuals with 9-11 years of schooling.

Most of the individuals of both genders watched TV and used a computer for more than three hours a day more than three times per week and performed heavy work for more than seven hours a week (Table 2).

As for physical activity, $65.0 \%$ of the individuals interviewed (95\% CI: 61.1-68.7) were classified as having sufficient levels

Table 1. Frequency distribution of sociodemographic characteristics, tobacco use, and nutritional status of the study sample according to gender. Bauru - SP, 2012

\begin{tabular}{|c|c|c|c|c|}
\hline \multirow{3}{*}{ Factors } & \multicolumn{4}{|c|}{ Gender } \\
\hline & \multicolumn{2}{|r|}{ Male } & \multicolumn{2}{|r|}{ Female } \\
\hline & $\mathbf{N}$ & $\%(95 \% \mathrm{CI})$ & $\mathbf{N}$ & $\%(95 \% \mathrm{CI})$ \\
\hline \multicolumn{5}{|l|}{ Schooling } \\
\hline $0-4$ years & 52 & $17.3(13.5-22.0)$ & 70 & $23.3(18.9-28.4)$ \\
\hline 5-8 years & 65 & $21.7(17.4-26.7)$ & 64 & $21.3(17.1-26.3)$ \\
\hline $9-11$ years & 126 & $42.0(36.6-47.7)$ & 118 & $39.3(34.0-45.0)$ \\
\hline$>12$ years & 57 & $19.0(15.0-23.8)$ & 48 & $16.1(12.3-20.6)$ \\
\hline \multicolumn{5}{|l|}{ Race } \\
\hline White & 237 & $79.0(74.0-83.2)$ & 243 & $81.0(76.2-85.0)$ \\
\hline African descent & 17 & $5.7(3.6-8.9)$ & 21 & $7.0(4.6-10.5)$ \\
\hline Brown/Mulatto & 46 & $15.3(11.7-19.8)$ & 36 & $12.0(8.8-16.2)$ \\
\hline \multicolumn{5}{|l|}{ Marital Status } \\
\hline Married & 180 & $60.0(54.4-65.4)$ & 165 & $55.0(49.3-60.5)$ \\
\hline Single & 85 & $28.3(23.5-33.7)$ & 65 & $21.7(17.4-26.7)$ \\
\hline $\begin{array}{l}\text { Widowed/ } \\
\text { Divorced }\end{array}$ & 35 & $11.7(8.5-1587)$ & 70 & $23.3(18.9-28.4)$ \\
\hline \multicolumn{5}{|l|}{ Income } \\
\hline Low & 189 & $63.0(57.4-68.3)$ & 200 & $66.7(61.2-71.8)$ \\
\hline Middle & 72 & $24.0(19.5-29.1)$ & 68 & $22.7(18.3-27.7)$ \\
\hline High & 39 & $13.0(9.7-17.3)$ & 32 & $10.6(7.7-14.7)$ \\
\hline \multicolumn{5}{|l|}{ Tobacco use } \\
\hline Non-smoker & 160 & $53.3(47.7-58.9)$ & 203 & $67.7(62.2-72.7)$ \\
\hline Former smoker & 74 & $24.7(20.1-29.8)$ & 54 & $18.0(14.1-22.7)$ \\
\hline Smoker & 66 & $22.0(17.7-27.0)$ & 43 & $14.3(10.8-18.8)$ \\
\hline \multicolumn{5}{|l|}{ Nutritional Status } \\
\hline Eutrophic & 123 & $41.0(35.6-46.6)$ & 132 & $44.0(38.5-49.7)$ \\
\hline Pre-obese & 116 & $38.7(33.3-44.3)$ & 96 & $32.0(27.0-37.5)$ \\
\hline Obese & 61 & $20.3(16.2-25.2)$ & 72 & $24.0(19.5-29.1)$ \\
\hline
\end{tabular}

CI: confidence intervals 
Table 2. Frequency distribution of variables associated with occupation and sedentary activities according to gender. Bauru - SP, 2012

\begin{tabular}{|c|c|c|c|c|}
\hline \multirow{3}{*}{ Variable } & \multicolumn{4}{|c|}{ Gender } \\
\hline & \multicolumn{2}{|c|}{ Male } & \multicolumn{2}{|c|}{ Female } \\
\hline & $\mathbf{N}$ & $\%(95 \% \mathrm{CI})$ & $\mathbf{N}$ & $\%(95 \% \mathrm{CI})$ \\
\hline \multicolumn{5}{|l|}{ TV viewing } \\
\hline No & 17 & $5.7(3.6-8.9)$ & 17 & $5.6(3.6-8.9)$ \\
\hline Yes & 283 & $94.3(91.1-96.4)$ & 283 & $94.3(91.1-96.4)$ \\
\hline \multicolumn{5}{|l|}{ TV/days } \\
\hline$\leq 2$ & 19 & $6.7(4.3-10.2)$ & 7 & $2.5(1.2-5.0)$ \\
\hline $3-4$ & 37 & $13.1(9.6-17.5)$ & 30 & $10.6(7.5-14.7)$ \\
\hline$\geq 5$ & 227 & $80.2(75.2-84-4)$ & 246 & $86.9(82.5-90.4)$ \\
\hline \multicolumn{5}{|l|}{ TV/hours/day } \\
\hline$\leq 2$ & 148 & $52.3(46.4-58.0)$ & 155 & $54.7(48.9-60.4)$ \\
\hline$>3$ & 135 & $47.7(41.9-53.5)$ & 128 & $45.2(39.5-51.1)$ \\
\hline \multicolumn{5}{|l|}{ Use of computer } \\
\hline No & 142 & $47.3(41.8-53.0)$ & 172 & $57.3(51.7-62.8)$ \\
\hline Yes & 158 & $52.7(47.0-58.2)$ & 128 & $42.7(37.2-48.3)$ \\
\hline \multicolumn{5}{|l|}{ Computer/days } \\
\hline$\leq 2$ & 17 & $10.8(6.8-16.6)$ & 20 & $15.6(10.3-22.9)$ \\
\hline $3-4$ & 23 & $14.6(9.9-20.9)$ & 13 & $10.2(6.0-16.6)$ \\
\hline$\geq 5$ & 118 & $74.7(67.4-80.8)$ & 95 & $74.2(66.0-81.0)$ \\
\hline \multicolumn{5}{|l|}{ Computer/hours/day } \\
\hline$\leq 2$ & 83 & $52.5(44.8-60.2)$ & 76 & $59.4(50.7-67.5)$ \\
\hline$>3$ & 75 & $47.5(39.8-55.2)$ & 52 & $40.6(32.5-49.3)$ \\
\hline \multicolumn{5}{|l|}{ Working hours/day } \\
\hline$<7$ & 27 & $9.0(6.3-12.8)$ & 77 & $25.7(21.1-30.9)$ \\
\hline$\geq 7$ & 273 & $91.0(87.2-93.7)$ & 223 & $74.3(69.1-78.9)$ \\
\hline \multicolumn{5}{|c|}{ Working in sitting position } \\
\hline Never/Rarely & 110 & $36.7(31.4-42.3)$ & 113 & $53.2(48.3-58.0)$ \\
\hline Usually/Always & 190 & $63.3(57.7-68.6)$ & 187 & $46.7(41.9-51.6)$ \\
\hline \multicolumn{5}{|l|}{ Heavy work } \\
\hline Never/ Rarely & 71 & $23.7(19.2-28.8)$ & 71 & $23.7(19.2-28.8)$ \\
\hline Usually/Always & 229 & $76.3(71.2-80.8)$ & 229 & $76.3(71.2-80.8)$ \\
\hline
\end{tabular}

and $35.0 \%$ (95\% CI: 31.2-38.9) as presenting insufficient levels. From those, $33.0 \%$ (95\% CI: 27.9-38.5) were male and $37.0 \%$ (95\% CI: 31.7-42.6) were female.

Insufficient practice of physical activities was significantly associated with low schooling for both genders, and with low income for males (Table 3).

No correlation was observed between insufficient practice of physical activities and number of working hours for women, and heavy work for men (Table 4).

Years of schooling (0-4), working in sitting position, and number of days of computer use per week remained associated with insufficient practice of physical activities in the final model for both genders. However, number of days of TV viewing per week was only associated with the male gender (Table 5).

\section{DISCUSSION}

Of all the individuals analyzed in this research, $36.3 \%$ were classified as having insufficient practice of physical activities, which corroborates the results of Belo Horizonte ${ }^{4}(33.7 \%)$ and the south/northeast ${ }^{5}$ regions (31.8\%). However, they are lower than those obtained in Joaçaba, Santa Catarina state ${ }^{17}-57.4 \%$, Brasília $^{10}(48.0 \%)$, and of individuals interviewed by the National Health Survey (PNS) - 46.0\%. Furthermore, data were greater than the results of Sao Paulo ${ }^{3}(17.3 \%)$ and Palmas $(18.7 \%)^{18}$.

Concerning gender, prevalence of insufficient practice of physical activities was similar to that of the Ribeirão Preto survey $^{8}$ and of women residing in Florianópolis ${ }^{9}$, and greater than the results verified in Belo Horizonte ${ }^{4}$ and Brasília ${ }^{10}$.

It was possible to observe that the same set of variables remained in the final model for both genders, except for number of days of TV viewing, which was only associated with men.

The fewer the years of schooling of individuals, the higher the risks of presenting the outcome $(p<0.01)$, corroborating the results of Brazilian ${ }^{8,19}$ and international ${ }^{20-22}$ studies; however, this was not observed in the south/northeast regions ${ }^{5}$, Brasília $^{10}$, and Juiz de Fora, Minas Gerais state ${ }^{23}$.

Adults with higher educational levels tend to present better conditions of health and income and, therefore, more facility, 
Table 3. Prevalence of insufficient practice of physical activities associated with sociodemographic variables, tobacco use, and nutritional status according to gender. Bauru - SP, 2012

\begin{tabular}{|c|c|c|c|c|c|c|}
\hline \multirow{3}{*}{ Variable } & \multicolumn{6}{|c|}{ Insufficient practice of physical activities } \\
\hline & \multicolumn{3}{|c|}{ Female } & \multicolumn{3}{|c|}{ Male } \\
\hline & $\mathbf{n}$ & $\%$ & PR (95\% CI) & $\mathbf{n}$ & $\%$ & PR $(95 \% \mathrm{CI})$ \\
\hline \multicolumn{7}{|l|}{ Age group } \\
\hline $20-35$ years & 57 & 57.0 & 1 & 67 & 67.0 & 1 \\
\hline $36-59$ years & 63 & 63.0 & $1.11(0.88-1.39)$ & 70 & 70.0 & $1.04(0.87-1.26)$ \\
\hline$\geq 60$ years & 69 & 69.0 & $1.21(0.98-1.50)$ & 64 & 64.0 & $0.96(0.78-1.17)$ \\
\hline \multicolumn{7}{|l|}{ Schooling } \\
\hline$\geq 9$ years & 95 & 57.2 & 1 & 102 & 59.0 & 1 \\
\hline $5-8$ years & 46 & 71.9 & $1.26(1.03-1.54)$ & 50 & 76.9 & $1.30(1.09-1.57)$ \\
\hline $0-4$ years & 48 & 68.6 & $1.20(0.98-1.47)$ & 39 & 75.0 & $1.27(1.04-1.55)$ \\
\hline \multicolumn{7}{|l|}{ Race } \\
\hline White & 154 & 63.4 & 1 & 158 & 66.7 & 1 \\
\hline African descent & 14 & 66.7 & $1.05(0.77-1.44)$ & 11 & 64.7 & $0.97(0.68-1.39)$ \\
\hline Brown/Mulatto & 21 & 58.3 & $0.92(0.69-1.23)$ & 32 & 69.6 & $1.04(0.84-1.29)$ \\
\hline \multicolumn{7}{|l|}{ Marital Status } \\
\hline Married & 104 & 63.0 & 1 & 115 & 63.8 & 1 \\
\hline Single & 35 & 53.8 & $0.85(0.66-1.10)$ & 61 & 71.8 & $1.12(0.95-1.34)$ \\
\hline Widowed/ Divorced & 50 & 71.4 & $1.13(0.94-1.37)$ & 25 & 71.4 & $1.12(0.88-1.42)$ \\
\hline \multicolumn{7}{|l|}{ Income } \\
\hline High & 30 & 63.8 & 1 & 19 & 48.7 & 1 \\
\hline Middle & 40 & 58.8 & $0.92(0.69-1.24)$ & 49 & 68.1 & $1.40(0.98-1.40)$ \\
\hline Low & 134 & & $1.05(0.83-1.33)$ & 133 & 70.4 & $1.44(1.02-2.02)$ \\
\hline \multicolumn{7}{|l|}{ Tobacco use } \\
\hline Non-smoker & 126 & 62.1 & 1 & 106 & 66.3 & 1 \\
\hline Former smoker & 36 & 66.7 & $1.07(0.86-1.33)$ & 52 & 70.3 & $1.06(0.88-1.28)$ \\
\hline Smoker & 27 & 62.8 & $1.01(0.78-1.30)$ & 43 & 65.2 & $0.98(0.80-1.21)$ \\
\hline \multicolumn{7}{|l|}{ Nutritional Status } \\
\hline Eutrophic & 89 & 67.4 & 1 & 76 & 61.8 & 1 \\
\hline Pre-obese & 53 & 55.2 & $0.82(0.66-1.02)$ & 82 & 70.7 & $1.14(0.95-1.37)$ \\
\hline Obese & 47 & & $0.97(0.79-1.19)$ & 43 & 70.5 & $1.14(0.92-1.41)$ \\
\hline
\end{tabular}

PR: prevalence ratios; CI: confidence intervals

Table 4. Prevalence of insufficient practice of physical activities associated with hours, type of occupation, and sedentary activities according to gender. Bauru - SP, 2012

\begin{tabular}{|c|c|c|c|c|c|c|}
\hline \multirow{3}{*}{ Variable } & \multicolumn{6}{|c|}{ Insufficient practice of physical activities } \\
\hline & \multicolumn{3}{|c|}{ Female } & \multicolumn{3}{|c|}{ Male } \\
\hline & $\mathbf{n}$ & $\%$ & PR (95\% CI) & $\mathbf{n}$ & $\%$ & (PR 95\% CI) \\
\hline \multicolumn{7}{|l|}{ TV/days } \\
\hline$\leq 2$ & 3 & 42.9 & 1 & 12 & 63.2 & 1 \\
\hline$\geq 3$ & 177 & 64.1 & $1.50(0.63-3.54)$ & 165 & 65.0 & $1.03(0.72-1.47)$ \\
\hline \multicolumn{7}{|l|}{ TV/hours/day } \\
\hline$\leq 2$ & 81 & 59.1 & 1 & 104 & 70.3 & 1 \\
\hline$\geq 3$ & 99 & 67.8 & $1.15(0.96-1.37)$ & 83 & 61.5 & $0.87(0.74-1.04)$ \\
\hline \multicolumn{7}{|l|}{ Computer/days } \\
\hline$\leq 2$ & 14 & 59.0 & 1 & 13 & 76.5 & 1 \\
\hline$\geq 3$ & 73 & 67.6 & $0.92(0.70-1.32)$ & 89 & 63.1 & $0.83(0.62-1.11)$ \\
\hline \multicolumn{7}{|l|}{ Computer/hours/day } \\
\hline$\leq 2$ & 35 & 59.3 & 1 & 54 & 67.5 & 1 \\
\hline$\geq 3$ & 52 & 75.4 & $1.27(0.99-1.63)$ & 57 & 73.1 & $1.08(0.88-1.33)$ \\
\hline \multicolumn{7}{|l|}{ Working hours/day } \\
\hline$<7$ & 39 & 50.6 & 1 & 17 & 63.0 & 1 \\
\hline$\geq 8$ & 150 & 67.3 & $1.33(1.05-1.69)$ & 184 & 67.0 & $1.07(0.79-1.45)$ \\
\hline \multicolumn{7}{|c|}{ Working in sitting position } \\
\hline Never/ Rarely & 65 & 67.4 & 1 & 57 & 51.8 & 1 \\
\hline Usually/Always & 126 & 57.5 & $1.17(0.97-1.41)$ & 134 & 70.5 & $1.36(1.11-1.67)$ \\
\hline \multicolumn{7}{|l|}{ Heavy work } \\
\hline Never/ Rarely & 51 & 66.2 & 1 & 127 & 67.9 & 1 \\
\hline Usually/Always & 140 & 62.8 & $0.95(0.78-1.14)$ & 64 & 56.6 & $0.83(0.69-1.01)$ \\
\hline
\end{tabular}

PR: prevalence ratios; CI: confidence intervals 
Table 5. Multivariate analysis of Poisson regression, final model, for associations of the studied variables with the physical activity practices of the study sample according to gender. Bauru - SP, 2012

\begin{tabular}{|c|c|c|c|}
\hline Variable & & $p$-value & PR $(95 \% \mathrm{CI})$ \\
\hline \multicolumn{4}{|c|}{ Male } \\
\hline \multirow[t]{3}{*}{ Schooling } & $\geq 9$ & & 1 \\
\hline & $5-8$ & 0.001 & $3.70(0.79-4.00)$ \\
\hline & $0-4$ & 0.004 & $2.30(1.21-4.06)$ \\
\hline \multirow[t]{2}{*}{ Number of days of TV viewing per week } & $\leq 2$ & 1 & \\
\hline & $\geq 3$ & 0.03 & $2.12(1.03-4.36)$ \\
\hline \multirow[t]{2}{*}{ Number of days of computer use per week } & $\leq 2$ & 1 & \\
\hline & $\geq 3$ & 0.004 & $2.04(1.26-3.32)$ \\
\hline \multirow[t]{2}{*}{ Working in sitting position } & Never/ Rarely & 1 & \\
\hline & Usually/Always & 0.001 & $2.22(1.36-3.62)$ \\
\hline \multicolumn{4}{|c|}{ Female } \\
\hline \multirow[t]{3}{*}{ Schooling } & $\geq 9$ & & 1 \\
\hline & $5-8$ & 0.39 & $1.34(0.66-2.63)$ \\
\hline & $0-4$ & 0.03 & $2.35(1.07-5.15)$ \\
\hline \multirow[t]{2}{*}{ Number of days of computer use per week } & $\leq 2$ & - & 1 \\
\hline & $\geq 3$ & 0.01 & $4.60(2.38-14.28)$ \\
\hline \multirow[t]{2}{*}{ Working in sitting position } & Never/ Rarely & - & 1 \\
\hline & Usually/Always & 0.03 & $1.52(1.02-2.48)$ \\
\hline
\end{tabular}

PR: prevalence ratios; CI: confidence intervals

access, and opportunities to practice physical activities, in addition to belonging to a social environment that recognizes physical activities as beneficial to health, which facilitates adherence ${ }^{7,8}$.

In the present study, men that watch TV more than three times a week present greater chances of presenting insufficient practice of physical activities. Studies conducted with adults in several countries and in Hong Kong showed an inverse relationship between time spent in sedentary activities and level of physical activities ${ }^{24,25}$. The time spent by individuals watching TV and using computers consumes a significant amount of their leisure time, which supports the hypothesis that the longer the time spent in sedentary activities, the lower the level of physical activity. It is important to emphasize that the time an individual spends sitting in front of the TV plays an important role in total inactive behavior and it is an accessible leisure option for specific groups, especially individuals with lower educational levels.

Individuals that usually or always perform their occupational tasks in sitting position or utilize computers more than three times a week presented greater chances of risk of insufficient practice of physical activities than those who have never performed these activities. Data from the National Health and Nutrition Examination Survey showed that individuals who execute activities in sitting position, such as finance market workers, mathematicians, and information technology analysts present higher prevalence of physical inactivity than those in all the other occupations ${ }^{26-28}$.
Findings of the present study show new data compared with those of other Brazilian population-based surveys, that is, insufficient practice of physical activity was associated with variables related to lifestyle and sedentary occupational activities. This fact reveals a change in behavior of the studied population, with a decrease in occupational and domestic activities related to heavy work and a clear increase in sedentary occupational and leisure activities, similar to what has occurred in other countries. Recent epidemiological studies have shown that excessive time spent in sedentary activities, in addition to being associated with cardiovascular diseases, obesity, metabolic syndrome, diabetes mellitus, and venous thrombosis, can be considered a risk factor of mortality, regardless of the level of physical activity.

Limitations to this survey include the lack of information on environmental and interpersonal factors, among others. Due to the cross-sectional nature of this study, any interpretation of the association between variables should be performed with caution with the purpose of considering the possibility of reverse causality in individual cases. An important aspect was the utilization of the International Physical Activity Questionnaire (IPAQ), which enabled comparison between these data and those of other studies.

Results of the present study show high prevalence of insufficient practice of physical activity for both genders. Such results were associated with schooling, working in sitting position, and number of days of computer use for both genders, and 
number of days of TV viewing for the males, considering the differences between genders.

Therefore, the development of strategies to stimulate the practice of physical activities is a fundamental issue, considering the differences between genders and socioeconomic factors.

\section{Acknowledgements}

The authors are especially grateful to the study participants, as well as to FAPESP (São Paulo Research Foundation) and CNPq (National Council for Scientific and Technological Development) for supporting the project.

\section{REFERENCES}

1. Allender S, Foster C, Scarborough P, Rayner M. The burden of physical activity-related ill health in the UK. J Epidemiol Community Health. 2007;61(4):344-8. http://dx.doi.org/10.1136/jech.2006.050807. PMid:17372296.

2. Shibata A, Oka K, Nakamura Y, Muraoka I. Prevalence and demographic correlates of meeting the physical activity recommendation among Japanese adults. J Phys Act Health. 2009;6(1):24-32. http://dx.doi.org/10.1123/ jpah.6.1.24. PMid:19211955.

3. Zanchetta LM, Barros MBA, César CLG, Carandina L, Goldbaum M, Alves MCGP. Inatividade física e fatores associados em adultos, São Paulo, Brasil. Rev Bras Epidemiol. 2010;13(3):387-99. http://dx.doi.org/10.1590/ S1415-790X2010000300003. PMid:20857026.

4. Ramalho JRO, Lopes ACS, Toledo MTT, Peixoto SV. Nível de atividade física e fatores associados ao sedentarismo em usuários de uma Unidade Básica de Saúde em Belo Horizonte, Minas Gerais. Rev Min Enferm. 2014;18(2):426-32.

5. Siqueira FV, Facchini LA, Piccini RX, Tomasi E, Thumé E, Silveira DS, et al Atividade física em adultos e idosos residentes em áreas de abrangência de unidades básicas de saúde de municípios das regiões Sul e Nordeste do Brasil. Cad Saude Publica. 2008;24(1):39-54. http://dx.doi.org/10.1590/ S0102-311X2008000100005. PMid:18209833.

6. Mielke GI, Hallal PC, Rodrigues GBA, Szwarcwald CL, Santos FV, Malta DC. Physical activity and television viewing among Brazilian adults: National Health Survey 2013. Epidemiol Serv Saude. 2015;24(2):277-86. http://dx.doi.org/10.5123/S1679-49742015000200010.

7. Uijtdewilligen L, Peeters GM, Van Uffelen JG, Twisk JW, Singh AS, Brown WJ. Determinants of physical activity in a cohort of young adult women. Who is at risk of inactive behaviour? J Sci Med Sport. 2015;18(1):49-55. http://dx.doi.org/10.1016/j.jsams.2014.02.005. PMid:24636128.

8. Suzuki CS, Moraes SA, Freitas ICM. Atividade física e fatores associados em adultos residentes em Ribeirão Preto. Rev Saude Publica. 2011;45(2):311-20. http://dx.doi.org/10.1590/S0034-89102011000200010. PMid:21412571.

9. Lopes JA, Longo GZ, Peres KG, Boing AF, Arruda MP. Fatores associados à atividade física insuficiente em adultos: estudo de base populacional no sul do Brasil. Rev Bras Epidemiol. 2010;13(4):689-98. http://dx.doi. org/10.1590/S1415-790X2010000400013. PMid:21180857.

10. Thomaz PM, Costa TH, Silva EF, Hallal PC. Fatores associados à atividade física em adultos, Brasília, DF. Rev Saude Publica. 2010;44(5):894-900. http://dx.doi.org/10.1590/S0034-89102010005000027. PMid:20802898.

11. Folstein MF, Folstein SE, McHugh PR. Mini-mental state: a practical method for grading the cognitive state of patients for the clinician. J Psychiatr Res. 1975;12(3):189-98. http://dx.doi.org/10.1016/0022-3956(75)90026-6. PMid:1202204.

12. Palma R, Conti MHS, Quintino NM, Gatti MAN, Simeão SFAP, Vitta A. Functional capacity and its associated factors in the elderly with low back pain. Acta Ortop Bras. 2014;22(6):295-9. http://dx.doi.org/10.1590/141378522014220600890. PMid:25538473.

13. Fernandes JAA, Genebra CVS, Maciel NM, Fiorelli A, Conti MHS, Vitta A. Low back pain in schoolchildren: a cross-sectional study in a western city of São Paulo State, Brazil. Acta Ortop Bras. 2015;23(5):235-8. http:// dx.doi.org/10.1590/1413-785220152305148842. PMid:26981028.

14. World Health Organization. Guidelines for controlling and monitoring the tobacco epidemic. Geneva: WHO; 1998.

15. Fernandes IT, Gallo PR, Advincula AO. Avaliação antropométrica de préescolares do município de Mogi-Guaçú, São Paulo: subsídio para políticas públicas de saúde. Rev Bras Saude Mater Infant. 2006;6(2):217-22. http:// dx.doi.org/10.1590/S1519-38292006000200009.

16. Craig CL, Marshall AL, Sjöström M, Bauman AE, Booth ML, Ainsworth $\mathrm{BE}$, et al. International physical activity questionnaire: 12-country reliability and validity. Med Sci Sports Exerc. 2003;35(8):1381-95. http://dx.doi. org/10.1249/01.MSS.0000078924.61453.FB. PMid:12900694.

17. Baretta E, Baretta M, Peres KG. Nível de atividade física e fatores associados em adultos no Município de Joaçaba, Santa Catarina, Brasil. Cad Saude Publica. 2007;23(7):1595-602. http://dx.doi.org/10.1590/S0102-311X2007000700010. PMid:17572808.

18. VIGITEL. Vigitel Brasil 2008 - Vigilância de fatores de risco e proteção para doenças crônicas por inquérito telefônico. Brasília: Ministério da Saúde; 2009.

19. Cunha IC, Peixoto MRG, Jardim PCBV, Alexandre VP. Fatores associados à prática de atividade física na população adulta de Goiânia. Rev Bras Epidemiol. 2008;11(3):495-504. http://dx.doi.org/10.1590/S1415-790X2008000300016.

20. Bernstein MS, Costanza MC, Morabia A. Physical activity of urban adults: a general population survey in Geneva. Soz Praventivmed. 2001;46(1):4959. http://dx.doi.org/10.1007/BF01318798. PMid:11320913.

21. Rütten A, Abu-Omar K. Prevalence of physical activity in the European Union. Soz Praventivmed. 2004;49(4):281-9. http://dx.doi.org/10.1007/ s00038-004-3100-4. PMid:15357531.

22. Camões M, Lopes $C$. Fatores associados à atividade física na população portuguesa. Rev Saude Publica. 2008;42(2):208-16. http://dx.doi.org/10.1590/ S0034-89102008000200004. PMid:18372972.

23. Silva GSF, Bergamaschine R, Rosa M, Melo C, Miranda R, Bara M Fo. Avaliação do nível de atividade física de estudantes de graduação das áreas saúde/biológica. Rev Bras Med Esporte. 2007;13(1):1-11. http://dx.doi. org/10.1590/S1517-86922007000100009.

24. Yang Y, An R, Zhu W. Physical activity and prolonged sedentary behavior in U.S. working adults. Arch Environ Occup Health. 2016;71(6):362-5. http://dx.doi.org/10.1080/19338244.2016.1151853. PMid:26862663. 
25. Vandelanotte C, Duncan MJ, Short C, Rockloff M, Ronan K, Happell $\mathrm{B}$, et al. Associations between occupational indicators and total, workbased and leisure-time sitting: a cross-sectional study. BMC Public Health. 2013;13(1):1110. http://dx.doi.org/10.1186/1471-2458-13-1110. PMid:24289321.

26. Hadgraft NT, Lynch BM, Clark BK, Healy GN, Owen N, Dunstan DW. Excessive sitting at work and at home: Correlates of occupational sitting and TV viewing time in working adults. BMC Public Health. 2015;15(1):899. http://dx.doi.org/10.1186/s12889-015-2243-y. PMid:26374514.

27. De Cocker K, Duncan MJ, Short C, Van Uffelen JG, Vandelanotte C. Understanding occupational sitting: prevalence, correlates and moderating effects in Australian employees. Prev Med. 2014;67:288-94. http://dx.doi. org/10.1016/j.ypmed.2014.07.031. PMid:25117522.

28. Saidj M, Menai M, Charreire H, Weber C, Enaux C, Aadahl M, et al. Descriptive study of sedentary behaviours in 35,444 French working adults: cross-sectional findings from the ACTI-Cités study. BMC Public Health. 2015;15(1):379. http://dx.doi.org/10.1186/s12889-015-1711-8. PMid:25884816.

Received on: Feb. 07, 2018 Accepted on: Jul. 192018 